\title{
STUDIES ON THE LEPROMIN REACTION
}

\section{LOT TESTS OF LEPROMIN POTENCY IN LEPROSY BACILLI AND TUBERCLE BACILLI SENSITIZED ANIMALS}

\author{
Ken YANAGISAWA and Nozomu ASAMI \\ (National Institute of Health)
}

The potency of 8 lots of Lepromin prepared at different times was tested in animals sensitized to leprosy bacilli and tubercle bacilli. The potency of the lots showed a similar trend in both groups of animals at 24 hours, and aside from a single lot, a similar trend was also observed at 48 hours.

The findings suggest that in view of the weak allergic response in leprosy bacilli sensitized animals and the difficulty in obtaining samples of leprosy bacilli, tubercle bacilli sensitized animals can be used for testing potency of Lepromin.

\section{Lepromin 反応に関する研究 (第 9 報)}

\section{瀨菌及び結核菌感作動物における \\ 各 Lot Lepromin の力価の比較実験}

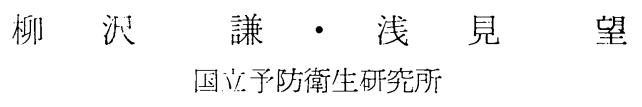

(1958 年: 10 月 2 日受稿)

緒訔

著者等は第 5 報11において，人型結核菌の死菌流動ハ ラフインで感作したモルモットを用い, Lepromin上 Tuberculin の各稀粎液々そ狄らの反応乞の関係を友た ところ, 再者とも濃度差に刘与る反店差性較的上く比 例したので，この感作動物に上るLepromin の力洒侙験 の可能であることを述べた。次で，第 7 派2)に拈いて製 造時期を翼にする 5 lot の Lepromin を結核感作動物と 瀨患者とに用いたところ, 力価の強さの傾向は両者とも 全く同一であつた。

その後，第 8 報3)に拀いて，瀨結節ふらトりプシン消 化法によつて分離した菌体を用い，モルモットを感作与 ることに成功した，今回はこの懶感作動物と結核菌感作 動物とに抢ける，各 lot Lepromin の力価の比較を行つ
たので報告けする。

\section{実 験 方 法}

\section{1. 感作動物}

a ）瀨菌：第 8 派3) に記載した方法（トリプシン消化 法）によつて分離した瀨菌 $2 \mathrm{mg}$ を Freund Adjuvant $0.5 \mathrm{cc}$ に浮遊した乳㓝を，体重 350 〜 $400 \mathrm{~g}$ の白色雌の モルモット14匹の両股部筋肉内に接種し，感作後 9 週目 にそのうち12匹を用いて力価試験を行つた。

b ) 結核菌：人型結核䒩青山 B 株の死菌の流動パラフ

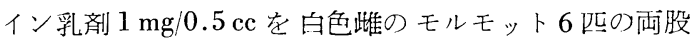
笳肉内に接種し，感作後，14週目に実験を行つた。

2. 注射试料

瀨研究協議会の成立した当初より予研に保存中の 8 lot のDharmendra 抗原を用いた。この場合の標準液と 
しては先て仮の標準液 (lot No. 1 及 2 の合せたもの) 艺用いた。この外瀨感作群には Tuberculin の 100 倍稀 釈液を, 結核感作群には Tuberculin の 2,000 倍稀釈液 を用いた。

第 1 表 Dharmendra 抗原の製造由来

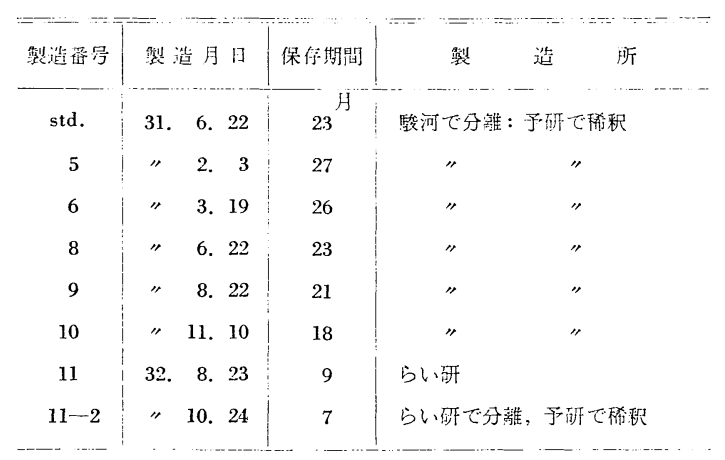

註：動物による力酩試䮖は 33. 5. 16〜6，4

\section{3. 注射方法}

両群とも 6 爬莸 1 群となし, 各動物の両背部及右獚腹 部 9 ケ所に各試料 $0.1 \mathrm{cc}$ ずつを皮内注射した,この際部

第 2 表 各 Lot Lepromin の瀨及び結核感作動物 に去ける力洒試験

\begin{tabular}{|c|c|c|c|c|c|c|c|c|c|}
\hline \multicolumn{3}{|c|}{ 感 作動物 } & \multirow{2}{*}{ 慜造番号 } & \multicolumn{2}{|c|}{ 硬結平均值 } & \multicolumn{2}{|c|}{ Ratio } & \multicolumn{2}{|c|}{ 强さの順位 } \\
\hline 種類 & 感作後 & 使用数 & & 24 & 48 & 24 & 48 & 24 & 48 \\
\hline \multirow{4}{*}{ 頪 } & \multirow{4}{*}{9} & \multirow{4}{*}{12} & std. & $\begin{array}{l}\mathrm{mm} \\
9.2\end{array}$ & $\begin{array}{l}\mathrm{mm} \\
6.9\end{array}$ & std. & std. & & \\
\hline & & & 5 & 7.7 & 6.1 . & 0.84 & 0.88 & 6 & 6 \\
\hline & & & 6 & 7.3 & 6.0 & 0.79 & 0.87 & 7 & 7 \\
\hline & & & 8 & 7.8 & 6.4 & 1.03 & 0.93 & 4 & 5 \\
\hline 菌 & 遠 & & 9 & 9.7 & 7.0 & 1.02 & 1.01 & 5 & 3 \\
\hline \multirow{4}{*}{$2 \mathrm{mg}$} & \multirow{4}{*}{ 後 } & \multirow{4}{*}{ 匹 } & 10 & 11.4 & 8.6 & 1.28 & 1.25 & 2 & 2 \\
\hline & & & 11 & 14.0 & 9.8 & 1.50 & 1.42 & 1 & 1 \\
\hline & & & $11-2$ & 10.5 & 6.7 & 1.14 & 1.00 & 3 & 4 \\
\hline & & & O T $100 x$ & 14.1 & 9.3 & & & & \\
\hline \multirow{3}{*}{ 結 } & \multirow{4}{*}{14} & \multirow{4}{*}{6} & std. & 14.3 & 12.7 & std. & std. & & \\
\hline & & & 5 & 9.0 & 7.0 & 0.63 & 0.55 & 7 & 7 \\
\hline & & & 6 & 9.7 & 7.2 & 0.67 & 0.56 & 6 & 6 \\
\hline \multirow[t]{2}{*}{ 核 } & & & 8 & 13.8 & 12.7 & 0.97 & 1.00 & 5 & 4 \\
\hline & \multirow[t]{2}{*}{ 週 } & \multirow{5}{*}{$\pi \tau$} & 9 & 14.3 & 11.5 & 1.00 & 0.91 & 4 & 5 \\
\hline 菌 & & & 10 & 16.8 & 14.7 & 1.17 & 1.16 & 2 & 2 \\
\hline \multirow{3}{*}{$1 \mathrm{mg}$} & \multirow{3}{*}{ 後 } & & 11 & 19.3 & 18.2 & 1.36 & 1.43 & 1 & 1 \\
\hline & & & $11-2$ & 15.5 & 14.7 & 1.09 & 1.16 & 3 & 3 \\
\hline & & & O T $2000 \times$ & 15.4 & 13.8 & & & & \\
\hline
\end{tabular}

位差学相殺するためラテン交絡法によつた。

4. 判定方法

注射後 24 及び 48 時間における硬結の大きさ省計測し た。

\section{実 験 成 績}

淕菌败結核菌感作動物に抄ける各 lot Lepromin に上 る反忍の大きさ並びに力価の比較は第 2 表の如くで市 る。

瀨菌感作群の 24 時間に尗ける反忘では, $10 \mathrm{~mm}$ 以上 のもの $3 \mathrm{lot}$ てての他は $9 \mathrm{~mm}$ 以下であつた，48時間で 浭に小さく6〜9.8 mm となつた。また，標準液（仮 りのもの）に対する力価壱みるに No. 5, 6 法弱く, No. 8，9 はほぼ等沈く，ての他 3 lot は強かつた，なお， O T 100 倍稀粐液に上る反态注 24 時間 $14.1 \mathrm{~mm}, 48$ 時 間 $9.3 \mathrm{~mm}$ であつた。

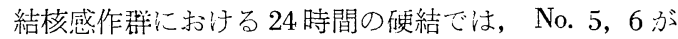
$10 \mathrm{~mm}$ 以下であるが，乙の他はすべて $10 \mathrm{~mm}$ 以上童示 した。48時間に打いてもこの 2 lot 以外は $10 \mathrm{~mm}$ 以上の 反応を保つた。ほた，標準液に対する力価は，No. 5,6

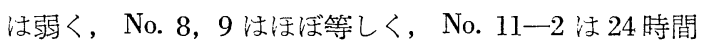
で注等力価だが，48時間ではやや強く，ての他の 2 lot は強かつた。なお，両感作群における反応の強さ䒚比較

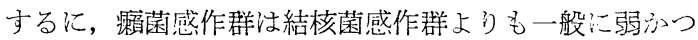
た。

次ぎに，両感作群における各 lot の力価の強さ老比献 寸ると第 3 表の如くである。

第 3 表 瀨及び結核感作動物におうナる 各製品の力価の強さの比較

\begin{tabular}{|c|c|c|}
\hline 判定 & 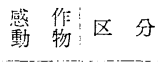 & $\begin{array}{c}1 \\
-\end{array}$ \\
\hline 24 & $\begin{array}{l}\text { Ratio } \\
\text { 顛 } \\
:\end{array}$ & $\begin{array}{c}1.501 .281 .14 \quad 1.03 \quad 1.02 \quad 0.84 \quad 0.79 \\
11>10>11-2>8=9>5=6\end{array}$ \\
\hline 間 & 結 核 $\begin{array}{l}\text { 强 さ } \\
\text { Ratio }\end{array}$ & $\begin{array}{c}11>10>11-2>9=8>6=5 \\
1.361 .17 \quad 1.09 \quad 1.00 \quad 0.97 \quad 0.67 \quad 0.63\end{array}$ \\
\hline 48 & Ratio & $\begin{array}{c}1.421 .251 .01 \quad 1.00 \quad 0.930 .880 .87 \\
11>10>9=11-2=8>5=6\end{array}$ \\
\hline 閂 & $\begin{array}{l}\text { 浊さ } \\
\text { 核 } \\
\text { Ratio }\end{array}$ & $\begin{array}{c}11>10=11-2>8=9>6=5 \\
1.431 .16 \quad 1.16 \quad 1.00 \quad 0.91 \quad 0.560 .55\end{array}$ \\
\hline
\end{tabular}

24. 時間値では両感作群とも No. 11 が最も強く, No. 10, 11一2, 8, 9 の順に漸次その強さを淢じ， No. 5 と 
6 とは最も弱かつた。また, No. 8 と 9 並びに 5 と 6 と は注ぼ等力価であつた。4 時間值に打いては両群とも No. 11 が最も強く, No. 10 これに次ぎ, No. 5 と 6 とは 最む弱く, No. 8 と 9 並びに 5 と 6 とはほぼ等力価であ ることは24時間值と同一であるが，No. 11-2 は瀨菌感 作群では No. 8 と等しく, 結核菌感作群では No. 10 と 等しかつた, この48時間における両群の不一致は癩菌感 作群の反応が弱いためであろう。

\section{総 括 及考按}

Chaussinand ${ }^{4)}$ は Lepromin の Standardization には 各種 Lepromin を瀨患者に用いた場合， L 型と $\mathrm{T}$ 型とに よる一致率をもつて決めているが，これでは濃度に著し い差のない限り区別すること注困難である。また，その 都度患者を用うることも容易なことではない。

著者等はさきに, 結核菌感作動物による Lepromin $の$ 力価試験が可能であり, かつ, この力価は $\mathrm{T}$ 型は患者に おける力価とほぼ等しかつたことを述べた。また, 顧菌 による感作群を得ることが出来たので, この感作群と結 核菌群とにおける力洒が同一であるか否かを調べた，そ のため製造時間を異にした 8 lot の Lepromin をこの両 感作群に用いたところ，24時間では全く同一傾向がみら れ，48 時間においても 1 lot 学除けばほぼ同一傾向を示 した。また, 反応の強さは一般に癩菌感作群は結核菌感 作群よりも弱いので, 方価の比較も前者では24時間值は ほぼ正しい価を示した。かくの如く, 両群が同一傾向を 有し, かつ, 瀨菌感作群のアレルギーが弱く, また, 瀨
菌の入手困難な現在においては，Lepromin の力価試験 には結核菌感作群を用いる方がよい成績を得るである う。

また，本実験からみれば，瀨菌と結核菌との間には感 作原性並びに皮内反応抗原性とも共通因子の存在が認め られる，このことに関しては別報に述べるつもりであ る。

今後に残された問題は Lepromin の標準液を決定する ことである。

\section{結言}

瀬菌感作群と結核菌感作群を用い，製造時期を異にし た 8 lot の Lepromin の力価試験を行つたところ，24時 間値では両群とも力洒の強さの傾向はよく一致した，ま た，48 時間値においても 1 lot を除いた他のものはほぼ 同一であつた。

稿を終るに当り灀結節を御提供下さいました，栗生楽 泉園後藤貞夫先生及び松ケ丘保養園荒川厳先生の御好意 を深謝する。

\section{文献}

1. 柳沢・浅見・石原：レプラ，25，198（1956）

2. 柳沢・浅見・石原：レプラ, 26, 261 (1957)

3. 柳沢・浅見：レプラ, 27, 107 (1958)

4. Chaussinand, R.: Internat. J. Lep., 24, 284 (1956) 